\title{
Development of multidrug-resistant Escherichia coli in some Egyptian veterinary farms
}

\author{
A. A. Samy (D), Asmaa S. Mansour(D), Doaa D. KhalafiD and Eman A. Khairy (iD \\ Department of Microbiology and Immunology, National Research Centre, Dokki, Cairo, Egypt. \\ Corresponding author: Asmaa S. Mansour, e-mail: asmaasami85@yahoo.com \\ Co-authors: AAS: ayman_samy@hotmail.com, DDK: doaa.khalaf@yahoo.com, EAK: emankhairy_77@yahoo.com \\ Received: 17-11-2021, Accepted: 20-01-2022, Published online: 27-02-2022
}

doi: www.doi.org/10.14202/vetworld.2022.488-495 How to cite this article: Samy AA, Mansour AS, Khalaf DD, Khairy EA (2022) Development of multidrug-resistant Escherichia coli in some Egyptian veterinary farms, Veterinary World, 15(2): 488-495.

\begin{abstract}
Background and Aim: Food of animal origin is considered a major source of foodborne diseases. In this context, multidrugresistant (MDR) Escherichia coli pose a serious hazard to public health due to the consumption of food contaminated with antibiotics that are used for the treatment of various bacterial infections in farm animals. Therefore, this study aimed to determine the effect of the excessive use of antibiotics on the development of MDR E. coli strains in Egyptian poultry, dairy, and meat farms.
\end{abstract}

Materials and Methods: A total of 1225 samples were randomly collected from poultry, dairy, and meat products intended for human consumption in different governorates. E. coli were isolated from the collected samples and subjected to biochemical identification and antibiotic sensitivity tests with antibiotics commonly used in human and veterinary medicine. Then, amoxicillin (AML)- and oxytetracycline (OT)-resistant $E$. coli isolates were subjected to a polymerase chain reaction test to detect the $b_{l} a_{\mathrm{TEM}}$ and tetA genes, respectively.

Results: E. coli were isolated from 132 out of 350,148 out of 350,177 out of 350 , and 35 out of 175 poultry, milk, meat, and human samples, respectively. Most of the isolates expressed multidrug resistance, and resistance genes (bla ${ }_{\mathrm{TEM}}$ and tet $\left.A\right)$ were detected in all the tested AML- and OT-resistant E. coli isolates.

Conclusion: Foods of animal origin may represent a source of MDR E. coli, which can be a major threat to public health.

Keywords: Escherichia coli, food of animal origin, misuse of antibiotics, multidrug resistance, poultry.

\section{Introduction}

Antibiotics are commonly used to treat bacterial infections in humans and animals. However, the association between the extensive use of antimicrobial agents and the progression of resistant bacteria has been well recognized in farm animals [1]. Over the past few years, antibiotic resistance among foodborne pathogens has increased [2]. Antimicrobials are drugs that are used to decrease the growth of microorganisms or even kill them. Antimicrobial resistance arises when bacteria resist these antimicrobial agents. The overuse of such agents to prevent or treat diseases or as growth promoters in animals is considered the main reason for the widespread antimicrobial resistance among farm animals. Antimicrobial resistance genes can be transmitted to humans through the ingestion of the milk or meat products of these animals. Humans and animals are major sources for contamination of other foods and the environment with resistant bacteria [3].

Copyright: Samy, et al. Open Access. This article is distributed under the terms of the Creative Commons Attribution 4.0 International License (http://creativecommons.org/licenses/by/4.0/), which permits unrestricted use, distribution, and reproduction in any medium, provided you give appropriate credit to the original author(s) and the source, provide a link to the Creative Commons license, and indicate if changes were made. The Creative Commons Public Domain Dedication waiver (http://creativecommons.org/ publicdomain/zero/1.0/) applies to the data made available in this article, unless otherwise stated.
Recently, many researchers have evaluated the antibiotic resistance of bacteria in food products [4,5]. The results showed that a major percentage of the strains isolated from foods of animal origin exhibited antibiotic resistance. In general, resistant microorganisms can transmit their resistance genes to the intestinal flora of humans, which act as a reservoir for these genes [6]. Animals can also act as a source of antimicrobial-resistant pathogens, hence posing a dangerous threat to public health [7]. For example, the high resistance of Escherichia coli to ciprofloxacin (CIP) is associated with the use of fluoroquinolones in agriculture [8]. As a result of the genetic flexibility and adaptability of $E$. coli to different environments, these microorganisms have developed numerous mechanisms to resist the action of antibiotics [9]. Such resistance may also be attributed to commensal strains in the lower intestinal tract being repeatedly challenged by antimicrobial pressure during the lifetime of the host. This causes them to acquire many resistance genes and/or develop resistant mutants to survive. Therefore, these microorganisms are considered an indicator of the antimicrobial load on their hosts [10].

This study aimed to investigate the effect of the overuse of antibiotics in Egyptian poultry, dairy, and meat farms on the development of multidrug-resistant (MDR) E. coli. 


\section{Materials and Methods}

\section{Ethical approval}

This study did not involve any in vivo experiments. Poultry, milk and milk products, meat and meat by product samples were collected from the market for microbiological studies, and human samples were obtained from Al-Sharq Laboratory, Haram, Giza, Egypt.

\section{Study period and location}

This study was conducted from June 2018 to May 2020 at the National Research Centre, Cairo, Egypt.

\section{Samples}

A total of 1225 samples were randomly obtained from different Egyptian governorates, including Cairo, Giza, Fayoum, Beni Suef, Menofia, Alexandria, and Qalyubia. All samples were grouped as shown in Table-1.

\section{Isolation and identification of $E$. coli isolates}

All samples were individually collected in sterile bags and transferred immediately under aseptic conditions in an icebox at $4^{\circ} \mathrm{C}$ and transferred to the laboratory for microbiological examination.

Briefly, $1 \mathrm{~g}$ or $1 \mathrm{~mL}$ of each sample was prepared in normal saline and cultured on the surface of a MacConkey agar medium (Oxoid, UK) to distinguish $E$. coli from other coliforms. The plates were then incubated at $37^{\circ} \mathrm{C}$ for $24 \mathrm{~h}$. Next, the suspected $E$. coli pink colonies were picked up, streaked on eosin methylene blue (EMB) agar (Lab M, UK), and incubated at $37^{\circ} \mathrm{C}$ for $24 \mathrm{~h}$. Finally, green metallic shiny colonies were subjected to morphological and biochemical identification, including oxidase, urease, indole production, methyl red, Voges-Proskauer, hydrogen sulfide, and citrate tests along with glucose, lactose, sorbitol, sucrose, and mannitol fermentation [11].

\section{Antibiotic sensitivity test of $E$. coli isolates}

First, the antibiotic sensitivity of the isolates was tested using the disk diffusion technique [12] against the most popular antibiotics used in the veterinary field, including cefradine (CR, 30 $\mathrm{g}$ ), CIP $(5 \mu \mathrm{g})$, oxytetracycline (OT, 30 $\mathrm{g})$, erythromycin (E, $15 \mu \mathrm{g})$, amoxicillin (AML, $10 \mu \mathrm{g})$, ampicillin (AMP, $10 \mu \mathrm{g}$ ), and streptomycin (S, 10 $\mu \mathrm{g})$. Then, $E$. coli isolates were cultured in nutrient broth (Oxoid) and incubated at $37^{\circ} \mathrm{C}$ for $18-24 \mathrm{~h}$. Next, a bacterial suspension of $0.5 \mathrm{McF}$ arland was prepared and streaked on Mueller-Hinton agar (Oxoid) plates using cotton swabs. Finally, antibiotic disks were placed on the surface of the plates followed by incubation at $37^{\circ} \mathrm{C}$ for $24 \mathrm{~h}$. After incubation, the inhibition zones were measured (in millimeters) using a ruler.

\section{Detection of AML- and OT-resistant E. coli using polymerase chain reaction (PCR)}

A total of 20 AML-resistant and 20 OT-resistant $E$. coli isolates (five isolates from each source) were randomly selected and examined for the presence of $\beta$-lactamase AML $\left(\right.$ bla $\left._{\mathrm{TEM}}\right)$ and OT (tetA) resistance genes, respectively.

\section{Bacterial genomic deoxyribonucleic acid (DNA) \\ extraction}

DNA extraction from bacterial isolates was performed using the QIAamp DNA Mini Kit (Qiagen $\mathrm{GmbH}$, Germany) as per the manufacturer's instructions with some modifications. Briefly, $200 \mu \mathrm{L}$ of the bacterial suspension was mixed with $10 \mu \mathrm{L}$ of proteinase $\mathrm{K}$ and $200 \mu \mathrm{L}$ of a lysis buffer and incubated for $10 \mathrm{~min}$ at $56^{\circ} \mathrm{C}$. Then, $200 \mu \mathrm{L}$ of $100 \%$ ethanol was added to the suspension, and the sample was washed and centrifuged. Elution of the nucleic acid was completed using $100 \mu \mathrm{L}$ of an elution buffer [13].

\section{PCR amplification}

The primers used in this study were purchased from Metabion (Germany) and are shown in Table-2 $[14,15]$. The reaction was performed in a volume of $25 \mu \mathrm{L}$ containing $12.5 \mu \mathrm{L}$ of EmeraldAmp MAX PCR Master Mix (Takara, Japan), $1 \mu \mathrm{L}$ of each primer $(20 \mathrm{pmol} / \mu \mathrm{L}), 6 \mu \mathrm{L}$ of a DNA template, and $4.5 \mu \mathrm{L}$ of nuclease-free water. Then, the reaction was completed in a Biometra thermal cycler according to the cycling conditions, as shown in Table-3.

\section{Electrophoresis}

First, the PCR products were analyzed by electrophoresis using $1.5 \%$ agarose gel in $1 \times$ Trisborate-ethylenediaminetetraacetic acid buffer at room temperature $\left(25^{\circ} \mathrm{C}\right)$. To perform a gel analysis, $20 \mu \mathrm{L}$ of uniplex PCR products were loaded in each gel slot. Then, a 100 bp DNA ladder (Fermentas, Thermo Fisher Scientific, USA) was used to determine the PCR product size. The gel was then visualized by a

Table-1: Types and numbers of samples collected for examination.

\begin{tabular}{llc}
\hline Sample & Types of samples examined & Total \\
\hline Poultry & $\begin{array}{l}\text { Liver, intestinal content, blood, } \\
\text { and bone marrow }\end{array}$ & 350 \\
$\begin{array}{l}\text { Milk and milk } \\
\text { by-products }\end{array}$ & $\begin{array}{l}\text { Yoghurt, raw milk, and Karish } \\
\text { cheese }\end{array}$ & 350 \\
$\begin{array}{l}\text { Meat and meat } \\
\text { by-products }\end{array}$ & $\begin{array}{l}\text { Luncheon, sausages, hotdogs, } \\
\text { minced meat, liver, kofta, } \\
\text { intestinal contents, and meat }\end{array}$ & 350 \\
Human & $\begin{array}{l}\text { Stools obtained from commercial } \\
\text { laboratories }\end{array}$ & 175 \\
Total & - & 1225 \\
\hline
\end{tabular}

Table-2: Target genes, primer sequences, amplicon sizes, and cycling conditions.

\begin{tabular}{llcc}
\hline $\begin{array}{l}\text { Target } \\
\text { gene }\end{array}$ & $\begin{array}{l}\text { Primer sequence } \\
\left(\mathbf{5}^{\prime}-\mathbf{3}^{\prime}\right)\end{array}$ & $\begin{array}{c}\text { Amplified } \\
\text { segment } \\
\text { (bp) }\end{array}$ & Reference \\
\hline$b l a_{\text {TEM }}$ & F: ATC AGC AAT AAA & 516 & {$[14]$} \\
& CCA GC & & \\
& R: CCC CGA AGA & & \\
tetA & ACG TTT TC & 576 & {$[15]$} \\
& F: GGT TCA CTC & & \\
& GAA CGA CGT CA & & \\
& R: CTG TCC GAC & & \\
& AAG TTG CAT GA & & \\
\hline
\end{tabular}


Table-3: Cycling conditions for the primers of the $b / a_{\mathrm{TEM}}$ and tetA genes.

\begin{tabular}{lccccc}
\hline Gene & Primary denaturation & \multicolumn{2}{c}{ Amplification (35 cycles) } & \multicolumn{2}{c}{ Final extension } \\
\cline { 3 - 5 } & & Secondary denaturation & Annealing & Extension \\
\hline bla ${ }_{\mathrm{TEM}}$ & $94^{\circ} \mathrm{C}$ & $94^{\circ} \mathrm{C}$ & $54^{\circ} \mathrm{C}$ & $72^{\circ} \mathrm{C}$ & $72^{\circ} \mathrm{C}$ \\
\multirow{2}{*}{ tet $A$} & $5 \mathrm{~min}$ & $30 \mathrm{~s}$ & $40 \mathrm{~s}$ & $45 \mathrm{~s}$ & $10 \mathrm{~min}$ \\
& $94^{\circ} \mathrm{C}$ & $94^{\circ} \mathrm{C}$ & $50^{\circ} \mathrm{C}$ & $72^{\circ} \mathrm{C}$ & $72^{\circ} \mathrm{C}$ \\
& $5 \mathrm{~min}$ & $30 \mathrm{~s}$ & $40 \mathrm{~s}$ & $45 \mathrm{~s}$ & $10 \mathrm{~min}$ \\
\hline
\end{tabular}

UV transilluminator, and the data were analyzed with computer software.

\section{Statistical analysis}

Data were computerized and analyzed Statistical Package for the Social Sciences Program Version 13 software for Windows (SPSS Inc., Chicago, III., USA) [16]. Furthermore, significant differences among means were detected by Duncan [17]. Oneway classification statistical fixed model was used for statistical analysis as the following:

$$
\mathrm{Y}_{\mathrm{ij}}=\mu+\mathrm{G}_{\mathrm{i}}+\mathrm{e}_{\mathrm{ij}}
$$

Where: $\mathrm{Y}_{\mathrm{ij}}$ is the $\mathrm{I}^{\text {th }}$ observation of the individual overall means, $\mu$ is the common mean, $G_{i}$ is the fixed effect of factor, and $\mathrm{e}_{\mathrm{ij}}$ is experimental error.

\section{Results}

Prevalence rate of $E$. coli isolates in poultry samples

A total of 132 out of 350 different samples of poultry origin were confirmed to have $E$. coli with a percentage of $37.7 \%$, as shown in Table-4.

Prevalence rate of $E$. coli isolates in milk and milk by-product samples

For milk and milk by-products, 148 isolates of E. coli were obtained from a total of 350 samples, representing a percentage of $42.3 \%$, as shown in Table-5.

Prevalence rate of $E$. coli isolates in meat and meat by-product samples

Table-6 shows the incidence rate of E. coli among a total of 350 meat and meat by-product samples, among which 177 samples were confirmed to have E. coli, representing a percentage of $50.6 \%$.

Prevalence rate of $\boldsymbol{E}$. coli isolates in human samples

As shown in Table-7, the recovery rate of $E$. coli from human samples was found to be $20.0 \%$ (35 out of 175 samples).

\section{Antimicrobial sensitivity test of $E$. coli isolated from poultry samples}

A total of 132 biochemically confirmed isolates of $E$. coli from poultry samples were tested for their antibiotic profile against seven different antibiotic agents. A pattern of multidrug resistance is observed in Table- 8 .

\section{Antimicrobial sensitivity test of $E$. coli isolated from milk samples}

A total of 148 isolates of E. coli from milk and milk by-products were examined for antibiotic resistance and reported in Table-9.
Table-4: Prevalence rates of E. coli isolates from poultry samples.

\begin{tabular}{|c|c|c|c|}
\hline \multirow[t]{2}{*}{$\begin{array}{l}\text { Sample } \\
\text { source }\end{array}$} & \multirow{2}{*}{$\begin{array}{c}\text { Total no. of } \\
\text { examined } \\
\text { samples }\end{array}$} & \multicolumn{2}{|c|}{$\begin{array}{c}\text { Recovered isolates of } \\
\text { E. coli }\end{array}$} \\
\hline & & No. & $\%$ \\
\hline Cairo & 50 & 17 & $34^{e}$ \\
\hline Giza & 50 & 18 & $36^{d}$ \\
\hline Fayoum & 50 & 20 & $40^{b}$ \\
\hline Beni Suef & 50 & 19 & $38^{c}$ \\
\hline Menofia & 50 & 17 & $34^{\mathrm{e}}$ \\
\hline Alexandria & 50 & 20 & $40^{\mathrm{b}}$ \\
\hline Qalyubia & 50 & 21 & $42^{a}$ \\
\hline Total & 350 & 132 & 37.7 \\
\hline p-value & & \multicolumn{2}{|c|}{$0.000 * *$} \\
\hline
\end{tabular}

$a, b, c$ Means in the same column bearing different superscripts are significantly different. **Significant differences at $\mathrm{p}=0.01, E$. coli $=$ Escherichia coli

Table-5: Prevalence rates of $E$. coli isolates from milk and milk by-products.

\begin{tabular}{lccc}
\hline $\begin{array}{l}\text { Sample } \\
\text { source }\end{array}$ & $\begin{array}{c}\text { No. of } \\
\text { examined } \\
\text { samples }\end{array}$ & $\begin{array}{c}\text { No. of recovered isolates } \\
\text { of } \begin{array}{c}\text { E. coli/total no. of } \\
\text { original samples }\end{array}\end{array}$ \\
\cline { 2 - 4 } & & No. & \% \\
\hline Cairo & 50 & 19 & $38.0^{\mathrm{d}}$ \\
Giza & 50 & 22 & $44.0^{\mathrm{c}}$ \\
Fayoum & 50 & 25 & $50.0^{\mathrm{b}}$ \\
Beni Suef & 50 & 16 & $32.0^{\mathrm{e}}$ \\
Menofia & 50 & 22 & $44.0^{\mathrm{c}}$ \\
Alexandria & 50 & 16 & $32.0^{\mathrm{e}}$ \\
Qalyubia & 50 & 28 & $56.0^{\mathrm{a}}$ \\
Total & 350 & 148 & 42.3 \\
p-value & \multicolumn{3}{c}{$0.000^{* *}$} \\
\hline
\end{tabular}

$a, b, c$ Means in the same column bearing different superscripts are significantly different. **Significant differences at $p=0.01$. E. coli=Escherichia coli

Antimicrobial sensitivity test of $E$. coli isolated from meat samples

As shown in Table-10, an antibiotic sensitivity pattern was observed for $E$. coli isolated from meat and meat by-products, revealing a high incidence of MDR E. coli.

Antimicrobial sensitivity test of $E$. coli isolated from human samples

Table-11 shows the antibiotic sensitivity profile of $E$. coli isolated from human samples. The results indicate a large number of resistant $E$. coli. The most prevalent resistance was found to be against $\mathrm{E}$ in all isolates. 
Results of the antibiotic resistance of $E$. coli among all samples

The antibiotic resistance of poultry, milk, meat, and human E. coli isolates is shown in Table-12. The most prevalent antibiotic resistance was found to be against $\mathrm{E}$ in most samples.

\section{Incidence of AML- and OT-resistant $E$. coli in differ- ent samples}

Table-13 shows the incidence rate of AML- and OT-resistant E. coli from different sources. The

Table-6: Prevalence rates of $E$. coli isolates in meat and meat by-products.

\begin{tabular}{|c|c|c|c|}
\hline \multirow[t]{2}{*}{$\begin{array}{l}\text { Sample } \\
\text { source }\end{array}$} & \multirow[t]{2}{*}{$\begin{array}{l}\text { No. of } \\
\text { examined } \\
\text { samples }\end{array}$} & \multicolumn{2}{|c|}{$\begin{array}{c}\text { No. of recovered isolates } \\
\text { of } E \text {. coli/total no. of } \\
\text { original samples }\end{array}$} \\
\hline & & No. & $\%$ \\
\hline Cairo & 50 & 23 & $46.0^{e}$ \\
\hline Giza & 50 & 29 & $58.0^{b}$ \\
\hline Fayoum & 50 & 26 & $52.0^{d}$ \\
\hline Beni Suef & 50 & 28 & $56.0^{c}$ \\
\hline Menofia & 50 & 22 & $44.0^{f}$ \\
\hline Alexandria & 50 & 19 & $38.0^{\mathrm{g}}$ \\
\hline Qalyubia & 50 & 30 & $60.0^{a}$ \\
\hline Total & 350 & 177 & 50.6 \\
\hline p-value & & \multicolumn{2}{|c|}{$0.000 * *$} \\
\hline
\end{tabular}

$a, b, c$ Means in the same column bearing different superscripts are significantly different. **Significant differences at $\mathrm{p}=0.01$. E. coli=Escherichia coli

Table-7: Prevalence rates of $E$. coli isolates from human samples.

\begin{tabular}{lccc}
\hline $\begin{array}{l}\text { Sample } \\
\text { source }\end{array}$ & $\begin{array}{c}\text { No. of } \\
\text { examined } \\
\text { samples }\end{array}$ & $\begin{array}{c}\text { Recovered isolates } \\
\text { of E. coli/total no. of } \\
\text { original samples }\end{array}$ \\
\cline { 2 - 4 } & & No. & \% \\
\hline Cairo & 25 & 6 & $24.0^{\mathrm{c}}$ \\
Giza & 25 & 7 & $28.0^{\mathrm{b}}$ \\
Fayoum & 25 & 5 & $20.0^{\mathrm{d}}$ \\
Beni Suef & 25 & 8 & $32.0^{\mathrm{a}}$ \\
Menofia & 25 & 4 & $16.0^{\mathrm{e}}$ \\
Alexandria & 25 & 2 & $8.0^{\mathrm{g}}$ \\
Qalyubia & 25 & 3 & $12.0^{\mathrm{h}}$ \\
Total & 175 & 35 & 20.0 \\
p-value & & \multicolumn{2}{c}{$0.000^{*} *$} \\
\hline
\end{tabular}

$a, b, c$ Means in the same column bearing different superscripts are significantly different. **Significant differences at $\mathrm{p}=0.01$. E. coli=Escherichia coli highest resistance against AML and OT was found among poultry samples with percentages of $83.3 \%$ and $90.2 \%$, respectively.

\section{Detection of AML- and OT-resistant E. coli by PCR}

As shown in Figures-1 and 2, all the tested AML- and OT-resistant isolates were found to carry the $b l a_{\mathrm{TEM}}$ and tet $A$ genes, respectively.

\section{Discussion}

All the isolated colonies were Gram-negative, motile, un sporulated bacilli. They demonstrated a lactose fermentation activity on MacConkey agar medium and had a greenish metallic shine on EMB agar. The isolates were also oxidase and urease negative, but indole and methyl red positive. They did not produce acetyl methyl carbinol during the VogesProskauer test or hydrogen sulfide on a triple sugar iron medium. They also failed to utilize citrate on the Simmons citrate medium, and they fermented glucose, lactose, sorbitol, sucrose, and mannitol [18].

Overall, 132 out of 350 poultry samples were confirmed to have E. coli, amounting to a percentage of $37.7 \%$. These $E$. coli were isolated from the internal organs of chickens, with a prevalence rate of $53.4 \%$ [19]. Moreover, 216 E. coli isolates were recovered from 270 whole chicken carcass samples [20]. However, the prevalence of colibacillosis was found to be $0.84 \%$ in broiler chickens and $0.80 \%$ in layer chickens [21]. For milk and milk by-products, 148 isolates of $E$. coli were obtained from a total of 350 samples, amounting to a percentage of $42.3 \%$. Moreover, $E$. coli were reported in milk samples [22], and a high occurrence rate of $E$. coli $\mathrm{O} 157: \mathrm{H} 7(34.3 \%)$ was found in dairy products [23]. In addition, $222 \mathrm{E}$. coli isolates were obtained from 187 samples of raw milk and dairy products [24], although a lower prevalence rate has been detected in Parseelan et al. [25]. Moreover, 177 out of 350 meat and meat by-product samples were confirmed to have $E$. coli (representing a percentage of $50.6 \%$ ). These results are in agreement with other studies [26,27], although Shaltout found lower prevalence rates for $E$. coli [28]. Finally, the recovery rate of $E$. coli from human samples was found to be $20.0 \%$ (35 out of 175 samples), demonstrating a high prevalence rate in humans according to many studies [29-31].

Table-8: Results of the antibiotic sensitivity test of $E$. coli isolated from poultry samples.

\begin{tabular}{|c|c|c|c|c|c|c|c|}
\hline \multirow[t]{2}{*}{ Antibiotic disks } & \multirow{2}{*}{$\begin{array}{l}\text { Total no. of } E . \text { coli } \\
\text { isolates }\end{array}$} & \multicolumn{2}{|c|}{ Resistant } & \multicolumn{2}{|c|}{ Sensitive } & \multicolumn{2}{|c|}{ Intermediate } \\
\hline & & No. & $\%$ & No. & $\%$ & No. & $\%$ \\
\hline Cefradine & 132 & 70 & $53.0^{f}$ & 44 & $33.3^{a}$ & 18 & $13.6^{c}$ \\
\hline Ciprofloxacin & 132 & 67 & $50.8^{g}$ & 33 & $25.0^{\mathrm{b}}$ & 32 & $24.2^{\mathrm{b}}$ \\
\hline Oxytetracycline & 132 & 119 & $90.2^{\mathrm{b}}$ & 13 & $9.8^{\mathrm{e}}$ & 0 & $0.0^{f}$ \\
\hline Erythromycin & 132 & 124 & $94.0^{\mathrm{a}}$ & 0 & $0.0^{\mathrm{g}}$ & 8 & $6.0^{d}$ \\
\hline Amoxicillin & 132 & 110 & $83.3^{c}$ & 22 & $16.6^{d}$ & 0 & $0.0^{f}$ \\
\hline Ampicillin & 132 & 100 & $75.8^{d}$ & 27 & $20.4^{c}$ & 5 & $3.8^{e}$ \\
\hline Streptomycin & 132 & 93 & $70.5^{e}$ & 4 & $3.0 f$ & 35 & $26.5^{a}$ \\
\hline p-value & & \multicolumn{2}{|c|}{$0.000 * *$} & \multicolumn{2}{|c|}{$0.000 * *$} & \multicolumn{2}{|c|}{$0.000 * *$} \\
\hline
\end{tabular}

$a, b, c$ Means in the same column bearing different superscripts are significantly different. **Significant differences at $\mathrm{p}=0.01$. . . coli=Escherichia coli 
Available at www.veterinaryworld.org/Vol.15/February-2022/32.pdf

Table-9: Results of the antibiotic sensitivity test of $E$. coli isolated from milk and milk by-products.

\begin{tabular}{|c|c|c|c|c|c|c|c|}
\hline \multirow[t]{2}{*}{ Antibiotic disks } & \multirow{2}{*}{$\begin{array}{l}\text { Total no. of } E . \text { coli } \\
\text { isolates }\end{array}$} & \multicolumn{2}{|c|}{ Resistant } & \multicolumn{2}{|c|}{ Sensitive } & \multicolumn{2}{|c|}{ Intermediate } \\
\hline & & No. & $\%$ & No. & $\%$ & No. & $\%$ \\
\hline Cefradine & 148 & 55 & $37.2^{b}$ & 85 & $57.4^{\mathrm{e}}$ & 8 & $5.4^{\mathrm{a}}$ \\
\hline Ciprofloxacin & 148 & 0 & $0.0^{\mathrm{e}}$ & 145 & $98.0^{a}$ & 3 & $2.0^{\mathrm{b}}$ \\
\hline Oxytetracycline & 148 & 30 & $20.3^{c}$ & 111 & $75.0^{d}$ & 7 & $5.7^{a}$ \\
\hline Erythromycin & 148 & 63 & $42.6^{a}$ & 85 & $57.4^{e}$ & 0 & $0.0^{c}$ \\
\hline Amoxicillin & 148 & 20 & $13.5^{e}$ & 128 & $86.5^{b}$ & 0 & $0.0^{c}$ \\
\hline Ampicillin & 148 & 29 & $19.6^{d}$ & 116 & $78.4^{c}$ & 3 & $2.0^{\mathrm{b}}$ \\
\hline Streptomycin & 148 & 0 & $0.0 \mathrm{e}$ & 145 & $98.0^{a}$ & 3 & $2.0^{\mathrm{b}}$ \\
\hline p-value & & \multicolumn{2}{|c|}{$0.000 * *$} & \multicolumn{2}{|c|}{$0.000 * *$} & \multicolumn{2}{|c|}{$0.000 * *$} \\
\hline
\end{tabular}

a,b,cMeans in the same column bearing different superscripts are significantly different. **Significant differences at $\mathrm{p}=0.01$. E. coli=Escherichia coli

Table-10: Results of the antibiotic sensitivity test of $E$. coli isolated from meat and meat by-products.

\begin{tabular}{|c|c|c|c|c|c|c|c|}
\hline \multirow[t]{2}{*}{ Antibiotic disks } & \multirow{2}{*}{$\begin{array}{l}\text { Total no. of } E . \text { coli } \\
\text { isolates }\end{array}$} & \multicolumn{2}{|c|}{ Resistant } & \multicolumn{2}{|c|}{ Sensitive } & \multicolumn{2}{|c|}{ Intermediate } \\
\hline & & No. & $\%$ & No. & $\%$ & No. & $\%$ \\
\hline Cefradine & 177 & 75 & $42.4^{b}$ & 95 & $53.6^{d}$ & 7 & $4.0^{f}$ \\
\hline Ciprofloxacin & 177 & 0 & $0.0^{f}$ & 174 & $98.3^{a}$ & 3 & $1.7^{\mathrm{g}}$ \\
\hline Oxytetracycline & 177 & 46 & $26.0^{d}$ & 120 & $67.8^{b}$ & 11 & $6.2^{\mathrm{e}}$ \\
\hline Erythromycin & 177 & 78 & $44.0^{\mathrm{a}}$ & 32 & $18.1^{\mathrm{g}}$ & 67 & $37.9^{b}$ \\
\hline Amoxicillin & 177 & 46 & $26.0^{d}$ & 102 & $57.6^{c}$ & 29 & $16.4^{d}$ \\
\hline Ampicillin & 177 & 55 & $31.1^{\mathrm{c}}$ & 86 & $48.6^{e}$ & 36 & $20.3^{c}$ \\
\hline Streptomycin & 177 & 11 & $6.2^{\mathrm{e}}$ & 85 & $48.0^{f}$ & 81 & $45.8^{a}$ \\
\hline $\mathrm{p}$-value & & \multicolumn{2}{|c|}{$0.000 * *$} & \multicolumn{2}{|c|}{$0.000 * *$} & \multicolumn{2}{|c|}{$0.000 * *$} \\
\hline
\end{tabular}

$a, b, c$ Means in the same column bearing different superscripts are significantly different. **Significant differences at $\mathrm{p}=0.01$. E. coli=Escherichia coli

Table-11: Results of the antibiotic sensitivity test of $E$. coli isolated from human samples.

\begin{tabular}{|c|c|c|c|c|c|c|c|}
\hline \multirow[t]{2}{*}{ Antibiotic disks } & \multirow{2}{*}{$\begin{array}{l}\text { Total no. of } E . \text { coli } \\
\text { isolates }\end{array}$} & \multicolumn{2}{|c|}{ Resistant } & \multicolumn{2}{|c|}{ Sensitive } & \multicolumn{2}{|c|}{ Intermediate } \\
\hline & & No. & $\%$ & No. & $\%$ & No. & $\%$ \\
\hline Cefradine & 35 & 17 & $48.5^{d}$ & 18 & $51.5^{b}$ & 0 & $0.0^{d}$ \\
\hline Ciprofloxacin & 35 & 9 & $25.7^{e}$ & 25 & $71.4^{\mathrm{a}}$ & 1 & $2.9^{c}$ \\
\hline Oxytetracycline & 35 & 24 & $68.6^{c}$ & 9 & $25.7^{c}$ & 2 & $5.7^{b}$ \\
\hline Erythromycin & 35 & 35 & $100.0^{a}$ & 0 & $0.0^{f}$ & 0 & $0.0^{d}$ \\
\hline Amoxicillin & 35 & 27 & $77.1^{b}$ & 6 & $17.1^{\mathrm{e}}$ & 2 & $5.7^{\mathrm{b}}$ \\
\hline Ampicillin & 35 & 24 & $68.6^{c}$ & 7 & $20.0^{d}$ & 4 & $11.4^{a}$ \\
\hline Streptomycin & 35 & 8 & $22.9^{f}$ & 25 & $71.4^{\mathrm{a}}$ & 2 & $5.7^{b}$ \\
\hline p-value & & \multicolumn{2}{|c|}{$0.000 * *$} & \multicolumn{2}{|c|}{$0.000 * *$} & \multicolumn{2}{|c|}{$0.000 * *$} \\
\hline
\end{tabular}

$a, b, c$ Means in the same column bearing different superscripts are significantly different. **Significant differences at $\mathrm{p}=0.01$. E. coli=Escherichia coli

Table-12: Results of the antibiotic resistance of $E$. coli from all samples.

\begin{tabular}{lcccc}
\hline $\begin{array}{l}\text { Antibiotic } \\
\text { disks }\end{array}$ & $\begin{array}{c}\text { E. coli/ } \\
\text { poultry }\end{array}$ & $\begin{array}{c}\text { E. coli/ } \\
\text { milk }\end{array}$ & $\begin{array}{c}\text { E. coli/ } \\
\text { meat }\end{array}$ & $\begin{array}{c}\text { E. coli/ } \\
\text { human }\end{array}$ \\
\hline Cefradine & $53.0^{\mathrm{f}}$ & $37.2^{\mathrm{b}}$ & $42.4^{\mathrm{b}}$ & $48.5^{\mathrm{d}}$ \\
Ciprofloxacin & $50.8^{\mathrm{g}}$ & $0.0^{\mathrm{f}}$ & $0.0^{\mathrm{f}}$ & $25.7^{\mathrm{e}}$ \\
Oxytetracycline & $90.2^{\mathrm{b}}$ & $20.3^{\mathrm{c}}$ & $26.0^{\mathrm{d}}$ & $68.6^{\mathrm{c}}$ \\
Erythromycin & $94.0^{\mathrm{a}}$ & $42.6^{\mathrm{a}}$ & $44.0^{\mathrm{a}}$ & $100.0^{\mathrm{a}}$ \\
Amoxicillin & $83.3^{\mathrm{c}}$ & $13.5^{\mathrm{e}}$ & $26.0^{\mathrm{d}}$ & $77.1^{\mathrm{b}}$ \\
Ampicillin & $75.8^{\mathrm{d}}$ & $19.6^{\mathrm{d}}$ & $31.1^{\mathrm{c}}$ & $68.6^{\mathrm{c}}$ \\
Streptomycin & $70.5^{\mathrm{e}}$ & $0.0 \mathrm{f}$ & $6.2^{\mathrm{e}}$ & $22.9^{\mathrm{e}}$ \\
p-value & $0.000^{* *}$ & $0.000^{* *}$ & $0.000^{* *}$ & $0.000^{* *}$ \\
\hline
\end{tabular}

a,b,cMeans in the same column bearing different superscripts are significantly different. **Significant differences at $\mathrm{p}=0.01$. E. coli=Escherichia coli

A total of 132 biochemically confirmed isolates of $E$. coli from poultry samples were tested for their antibiotic profile against seven different antibiotic agents. The most prevalent type of resistance was against $\mathrm{E}$, which was detected in 124 isolates (94.0\%). Moreover, a high level of resistance was found against other antibiotics, such as OT, AML, AMP, S, CR, and CIP. Notably, many authors have studied the multidrug resistance of $E$. coli in poultry samples and the wide distribution of antibiotic-resistant bacteria in raw chicken meat [32]. With the disk diffusion method, the results showed that nearly $192(89 \%)$ of the 216 isolates were resistant to at least one antibiotic [20].

Moreover, 148 isolates of E. coli from milk and milk by-products were screened for antibiotic resistance. The results revealed a high incidence rate of antibiotic resistance against $\mathrm{E}$, followed by CR, OT, AMP, and AML. However, none of the isolates demonstrated resistance to CIP or S. In many other studies, $E$. coli strains isolated from milk and dairy products revealed high antibiotic resistance against different 
Table-13: Prevalence rates of amoxicillin- and oxytetracycline-resistant $E$. coli from different sources.

\begin{tabular}{|c|c|c|c|c|c|c|c|}
\hline \multirow[t]{2}{*}{ Sample source } & \multirow[t]{2}{*}{ No. of examined samples } & \multicolumn{2}{|c|}{$\begin{array}{c}\text { No. of recovered } \\
\text { E. coli }\end{array}$} & \multicolumn{2}{|c|}{$\begin{array}{l}\text { Amoxicillin } \\
\text { resistant }\end{array}$} & \multicolumn{2}{|c|}{$\begin{array}{l}\text { Oxytetracycline } \\
\text { resistant }\end{array}$} \\
\hline & & No. & $\%$ & No. & $\%$ & No. & $\%$ \\
\hline Poultry & 350 & 132 & $37.7^{c}$ & 110 & $83.3^{a}$ & 119 & $90.2^{\mathrm{a}}$ \\
\hline Milk and its by-products & 350 & 148 & $42.3^{b}$ & 20 & $13.5^{d}$ & 30 & $20.3^{d}$ \\
\hline Meat and its by-products & 350 & 177 & $50.6^{a}$ & 46 & $26.0^{c}$ & 46 & $26.0^{c}$ \\
\hline Human & 175 & 35 & $20.0^{d}$ & 27 & $77.1^{\mathrm{b}}$ & 24 & $68.6^{b}$ \\
\hline Total & 1,225 & 492 & 40.2 & 203 & 41.3 & 219 & 44.5 \\
\hline$p$-value & & \multicolumn{2}{|c|}{$0.000 * *$} & \multicolumn{2}{|c|}{$0.000 * *$} & \multicolumn{2}{|c|}{$0.000 * *$} \\
\hline
\end{tabular}

$\mathrm{a}, \mathrm{b}, \mathrm{c}$ Means in the same column bearing different superscripts are significantly different. $* *$ Significant differences at $\mathrm{p}=0.01$. E. coli $=$ Escherichia coli

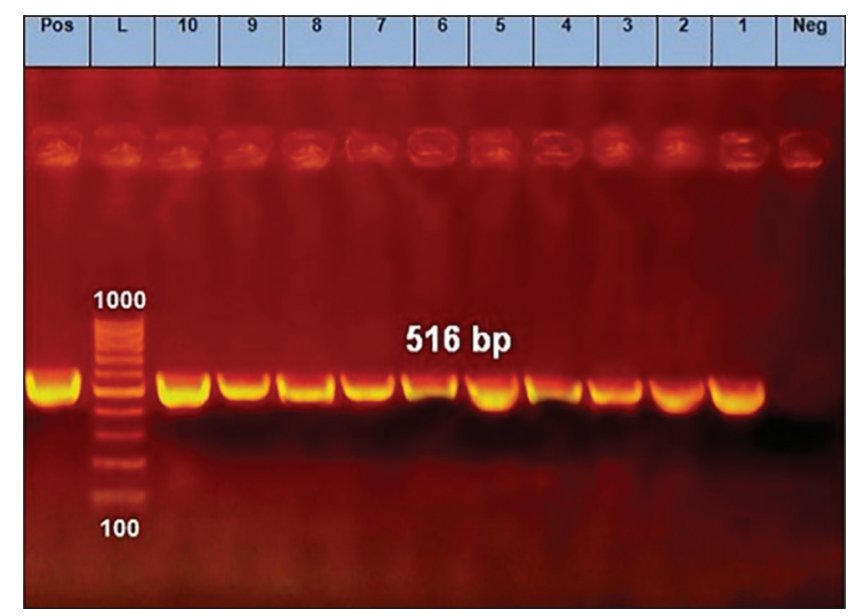

Figure-1: Polymerase chain reaction results of amoxicillinresistant Escherichia coli isolates (bla ${ }_{\mathrm{TEM}}$ gene). Lane=Lanes 1 to 10 depict positive amplification of the bla $a_{\text {TEM }}$ gene at $516 \mathrm{pb}, \mathrm{Neg}=$ Negative control, Pos=Positive control, $\mathrm{L}=$ Marker.

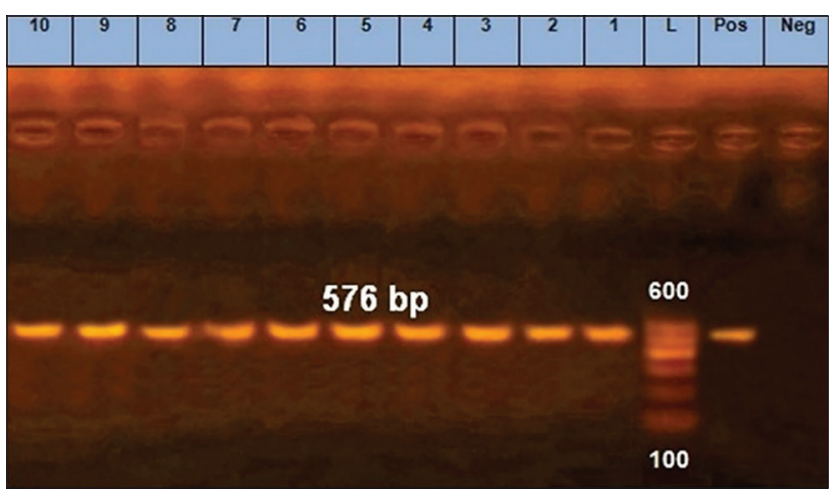

Figure-2: Polymerase chain reaction results of oxytetracycline-resistant Escherichia coli isolates (tetA (A) gene). Lane=Lanes 1 to 10 depict positive amplification of the tet $A(A)$ gene at $576 \mathrm{bp}, \mathrm{Neg}=$ Negative control, Pos=Positive control, $L=$ Marker.

antibiotics [33-36]. In addition, an antibiotic sensitivity pattern was observed for $E$. coli isolates from meat and meat by-products, revealing a high rate of resistance against E, followed by CR, AMP, OT, AML, and S. However, none of the isolates was resistant to CIP. Moreover, 46 E. coli isolates from 200 meat samples were identified as extended-spectrum $\beta$-lactamase-producing E. coli (ESBL-Ec) [37], and other studies revealed high antibiotic resistance [38-41]. Finally, the antibiotic sensitivity profile of human
E. coli isolates was investigated, and a large number of resistant $E$. coli were detected, mainly to E in all isolates, with a percentage of $100 \%$, followed by AML, OT, AMP, and CR. Many researchers have detected antibiotic resistance in $E$. coli strains isolated from human samples [12,42]. Overall, antibiotic resistance was found in poultry, milk, meat, and human isolates, with the most prevalent rate of resistance being against $E$ in most samples. A high incidence rate of resistance between human isolates and isolates of food of animal origin was also observed. Hence, a special correlation was found in $\mathrm{E}$ resistance in human $(100.0 \%)$, poultry $(94.0 \%)$, meat $(44.0 \%)$, and milk (42.6\%) samples. In addition, a high incidence rate of antibiotic resistance against AML was found between human $(77.1 \%)$ and poultry $(83.3 \%)$ samples. The same correlation was also noticed in the high resistance against OT and AMP between human (68.6\% each) and poultry $(90.2 \%$ and $75.8 \%$, respectively) samples. These results highlight the heavy use of these antibiotics in the poultry farming industry in Egypt, which may point to the transmission of resistance genes from foods of animal origin to humans. A recent study revealed ESBL genes in ESBL-Ec isolated from farmers and their chickens, and genomic similarity analysis demonstrated the involvement of ESBL-Ec between farmers and chickens [43]. These results are in line with other studies [32,34,37]. When PCR was used, all of the tested AML- and OT-resistant isolates were found to carry the $b l a_{\mathrm{TEM}}$ and tetA genes, respectively. The same genes were detected in many recent studies on AML- and OT-resistant E. coli $[9,44-47]$. Hence, it can be concluded that there is a direct relationship between the use of antibiotics in poultry farms and the presence of antibiotic-resistant bacteria in humans $[48,49]$. This highlights the importance of decreasing the use of antibiotics in human and veterinary medicine.

\section{Conclusion}

In this study, E. coli were isolated from food of animal origin, including poultry, milk and by-products, and meat and by-products in addition to human stools with high percentages. The isolates were identified with morphological and biochemical techniques. Molecular analysis was not performed for the 
identification of strains which can be considered as the limitation of the study. It was found that $E$. coli strains were resistant to CR, OT, E, AML, AMP, and S. CIP resistance was found in bacterial isolates concerning poultry and human samples only. This points to excessive use of this antibiotic in poultry farms. Some AML- and OT-resistant strains were confirmed using PCR and all of them were found to have $b l a_{\text {TEM }}$ and tet $A$ genes, respectively. These findings indicate a strong relationship between the misuse of antibiotics in the veterinary field and the development of resistant pathogens in humans. Therefore, strict measures should be applied to control the spread of resistant bacterial strains through bacterial culturing, phenotypic identification, and antibiotic sensitivity tests to determine the drug of choice and misuse of antibiotics could be prevented. Moreover, antibiotics used as growth promoters should be avoided in veterinary farms. The government should make great efforts including the use of antibiotics in the poultry and animal farms after consulting veterinarians, encouraging one health surveillance efforts, development of rapid diagnostic tests for antibiotic resistance, and encouraging local and international collaboration for antibiotic resistance prevention and control.

\section{Authors' Contributions}

AAS: Designed the study and drafted the manuscript. ASM: Revised the manuscript. AAS, ASM, DDK, and EAK: Contributed to the laboratory work. All authors have read and approved the final manuscript.

\section{Acknowledgments}

This study was funded by the National Research Centre, Egypt (project number 11020305).

\section{Competing Interests} interests.

The authors declare that they have no competing

\section{Publisher's Note}

Veterinary World remains neutral with regard to jurisdictional claims in published institutional affiliation.

\section{References}

1. Talebiyan, R., Kheradmand, M., Khamesipour, F. and Rabiee-Faradonbeh, M. (2014) Multiple antimicrobial resistance of $E$. coli isolated from chickens in Iran. Vet. Med. Int., 2014: 491418.

2. de Been, M., Lanza, V.F., de Toro, M., Scharringa, J., Dohmen, W., Du, Y., Hu, J., Lei, Y., Li, N., ToomingKlunderud, A., Heederik, D.J., Fluit, A.C., Bonten, M.J., Willems, R.J., de la Cruz, F. and van Schaik, W. (2014) Dissemination of cephalosporin resistance genes between $E$. coli strains from farm animals and humans by specific plasmid lineages. PLoS Genet., 10(12): e1004776.

3. Adzitey, F., Huda, N. and Shariff, A.H.M. (2021) Phenotypic antimicrobial susceptibility of $E$. coli from raw meats, ready-to-eat meats, and their related samples in one health context. Microorganisms, 9(2): 1-11.
4. Munsch-Alatossava, P. and Alatossava, T. (2007) Antibiotic resistance of raw-milk-associated psychrotrophic bacteria. Microbiol. Res., 162(2): 115-123.

5. Adesiji, Y.O., Deekshit, V.K. and Karunasagar, I. (2014) Antimicrobial-resistant genes associated with Salmonella spp. isolated from human, poultry, and seafood sources. Food Sci. Nutr., 2(4): 436-442.

6. Aarestrup, F.M., Wegener, H.C. and Collignon, P. (2008) Resistance in bacteria of the food chain: Epidemiology and control strategies. Expert Rev. Anti. Infect. Ther., 6(5): 733-750.

7. Wright, G.D. (2010) Antibiotic resistance in the environment: A link to the clinic. Curr. Opin. Microbiol., 13(5): 589-594.

8. Rice, L.B., Sahm, D. and Binomo, R.A. (2003) Mechanisms of resistance to antibacterial agents. In Manual of Clinical Microbiology. ASM Press, Washington, DC. p1074-1101.

9. Rubab, M. and Oh, D.H. (2021) Molecular detection of antibiotic resistance genes in Shiga toxin-producing E. coli isolated from different sources. Antibiotics, 10(4): 344.

10. Szmolka, A. and Nagy B. (2013) Multidrug-resistant commensal $E$. coli in animals and its impact on public health. Front Microbiol., 4: 258.

11. Islam, N.N., Nur, S.M., Farzana, Z., Uddin, I. Kamaruddin, A.M. and Siddiki, A.M.N. (2014) Rapid identification of eosin methylene blue positive $E$. coli by specific PCR from frozen chicken rinse in Southern Chittagong city of Bangladesh: Prevalence and antibiotic susceptibility. Microbiol. J., 4(2): 27-40.

12. Omololu-Aso, O.O., Egbedokun, A., Otusanya, O.O., Omololu-Aso, J., Owolabi, A.T. and Oluwasanmi, A.V. (2017) Antibiotic susceptibility pattern of E. coli isolated from out-patient individuals attending the University College Hospital (UCH), Ibadan, Nigeria. J. Infec. Dis. Treat., 3:1.

13. Abd El-Tawab, A.A., Maarouf, A.A. and El-Sayed, A.M.A. (2019) Bacteriological and molecular studies on antibiotic-resistant $E$. coli isolated from meat and its products in Kaliobia, Egypt. BVMJ, 36(2): 335-344.

14. Colom, K., Pèrez, J., Alonso, R., Fernández-Aranguiz, A., Lariňo, E. and Cisterna, R. (2003) Simple and reliable multiplex PCR assay for detection of $\mathrm{bla}_{\mathrm{TEM}}, \mathrm{bla}_{\mathrm{SHV}}$ and bla $_{\text {OXA-1 }}$ genes in Enterobacteriaceae. FEMS Microbiol. Lett., 223(2): 147-151.

15. Randall, L.P., Cooles, S.W., Osborn, M.K., Piddock, L.J.V. and Woodward, M.J. (2004) Antibiotic resistance genes, integrons and multiple antibiotic resistance in thirty-five serotypes of Salmonella enterica isolated from humans and animals in the UK. J. Antimicrob. Chemother., 53(2): 208-216.

16. SPSS Program. (1999) User's Guide Statistic. Release No. 10.01. SPSS Inc., USA.

17. Duncan, D.B. (1955) Multiple range and multiple f. Test Biom., 11: 1-42

18. Quinn, P.J., Markey, B.K., Carter, M.E., Donnelly, W.J.C., Leonard, F.C. and Maguire, D. (2002) Veterinary Microbiology and Microbial Diseases. $1^{\text {st }}$ ed. Blackwell Science, New Jersey, United States.

19. Ibrahim, R.A., Cryer, T.L., Lafi, S.Q., Abu Basha, E., Good, L. and Tarazi, Y.H. (2019) Identification of E. coli from broiler chickens in Jordan, their antimicrobial resistance, gene characterization and the associated risk factors. BMC Vet. Res., 15(1): 159.

20. Eltai, N.O., Yassine, H.M., El-obeid, T., Al-hadidi, S.H., Al Thani, A.A. and Alali, W.Q. (2020) Prevalence of antibiotic-resistant $E$. coli isolates from local and imported retail chicken carcasses. J. Food Prot., 83(12): 2200-2208.

21. Matin, M.A., Islam, M.A. Khatun, M.M. (2017) Prevalence of colibacillosis in chickens in greater Mymensingh district of Bangladesh. Vet. World, 10(1): 29-33.

22. Hinthong, W., Pumipuntu, N., Santajit, S., Kulpeanprasit, S., Buranasinsup, S., Sookrung, N., Chaicumpa, W., 
Aiumurai, P. and Indrawattana, N. (2017) Detection and drug resistance profile of $E$. coli from subclinical mastitis cows and water supply in dairy farms in Saraburi Province, Thailand. Peer J., 5: e3431.

23. Kunadu, A.P., Holmes, M., Miller, E.L. and Grant, A.J. (2018) Microbiological quality and antimicrobial resistance characterization of Salmonella spp. in fresh milk value chains in Ghana. Int. J. Food Microbiol., 277: 41-49.

24. Ombarak, R.A., Hinenoya, A., Awasthi, S.P., Iguchi, A., Shima, A., Elbagory, A.M. and Yamasaki, S. (2016) Prevalence and pathogenic potential of $\mathrm{E}$. coli isolates from raw milk and raw milk cheese in Egypt. Int. J. Food Microbiol., 221: 69-76.

25. Parseelan, A., Mutthu, S., Kannan, P., Narayanan, R., Ayyasamy, E. and Muthukumarasamy, S. (2018) Distribution of $E$. coli in milk and dairy products marketed in different zones of Chennai Metropolis. Int. J. Livest. Res., 8(11): 327-332.

26. Liu, S., Kilonzo-Nthenge, A., Nahashon, S.N., Pokharel, B., Ibn Mafiz, A. and Nzomo, M. (2020) Prevalence of multidrug-resistant foodborne pathogens and indicator bacteria from edible offal and muscle meats in Nashville, Tennessee. Foods, 9(9): 1190.

27. Adzitey, F., Assoah-Peprah, P., Teye, G.A., Somboro, A.M., Kumalo, H.M. and Amoako, D.G. (2020) Prevalence and antimicrobial resistance of $E$. coli isolated from various meat types in the Tamale Metropolis of Ghana. Int. J. Food Sci., 2020: 8877196.

28. Shaltout, F.A., Maarouf, A.A.A., El-Kewaiey, I.A. and Heweidy, A.Y.A. (2016) Prevalence of some foodborne microorganisms in meat and meat products. BVMJ, 31(2): 213-219.

29. Cho, S., Hiott, L.M., Barrett, J.B., McMillan, E.A., House, S.L., Humayoun, S.B., Adams, E.S., Jackson, C.R. and Frye, J.G. (2018) Prevalence and characterization of $E$. coli isolated from the Upper Oconee Watershed in Northeast Georgia. PLoS One, 13(5): e0197005.

30. Eltai, N.O., Yassine, H.M., Al Thani, A.A., Abu Madi, M.A., Ismail, A., Ibrahim, E. and Alali, W.Q. (2018) Prevalence of antibiotic-resistant $E$. coli isolates from fecal samples of food handlers in Qatar. Antimicrob. Resist. Infect. Control, 7: 78.

31. Aabed, K., Moubayed, N. and Alzahrani, S. (2021) Antimicrobial resistance patterns among different E. coli isolates in the Kingdom of Saudi Arabia. Saudi J. Biol. Sci., 28(7): 3776-3782.

32. Shrestha, A., Bajracharya, A.M., Subedi, H., Turha, R.S., Kafle, S., Sharma, S., Neupane, S. and Chaudhary, D.K. (2017) Multidrug resistance and extended-spectrum beta-lactamase producing Gram-negative bacteria from chicken meat in Bharatpur Metropolitan, Nepal. BMC Res. Notes, 10(1): 574.

33. Hasan, A., Reza, M.A., Rume, F.I., Meher, M.M., Parvej, M.S. and Anower A.K.M. (2018) Prevalence and antibiotic resistance pattern of $E$. coli isolated from raw dairy milk. TURJAF, 6(9): 1108-1113.

34. Tadesse, H.A., Gidey, N.B., Workelule, K., Hailu, H., Gidey, S., Bsrat, A. and Taddele, H. (2018) Antimicrobial resistance profile of $E$. coli isolated from raw cow milk and fresh fruit juice in Mekelle, Tigray, Ethiopia. Vet. Med. Int., 2018: 8903142 .

35. Sudda, M.M., Mtenga, A.B., Kusiluka, L.J. and Kassim, N. (2016) Prevalence and antibiotic susceptibility of E. coli and Salmonella spp. isolated from milk of zero grazed cows in Arusha city. Afr. J. Microbiol. Res., 10(46): 1944-1951.

36. Yohannes, G. (2018) Isolation, identification and antimicrobial susceptibility testing of $E$. coli isolated from selected dairy farms in and around Mekelle, Ethiopia. $J$. Dairy Vet. Anim. Res., 7(6): 287-291.

37. Eibach, D., Dekker, D., Boahen K.G., Akenten, C.W., Sarpong, N., Campos C.B., Berneking, L., Aepfelbacher, M., Krumkamp, R., Owusu-Dabo, E. and May, J. (2018) Extended-spectrum beta-lactamase-producing $E$. coli and $K$. pneumoniae in local and imported poultry meat in Ghana. Vet. Microbiol., 217: 7-12.

38. Jans, C., Sarno, E., Collineau, L., Meile, L., Stärk, K.D.C. and Stephan, R. (2018) Consumer exposure to antimicrobial-resistant bacteria from food at Swiss retail level. Front Microbiol., 9: 362.

39. Kylie, J., McEwen, S.A., Boerlin, P., Reid-Smith, R.J., Weese, J.S. and Turner, P.V. (2017) Prevalence of antimicrobial resistance in fecal $E$. coli and $S$. enterica in Canadian commercial meat, companion, laboratory, and shelter rabbits (Oryctolagus cuniculus) and its association with routine antimicrobial use in commercial meat rabbits. Prev. Vet. Med., 147: 53-57.

40. Martínez-Vázquez, A.V., Vázquez-Villanueva, J., Leyva-Zapata, L.M., Barrios-García, H., Rivera, G. and Bocanegra-García, V. (2021) Multidrug resistance of E. coli strains isolated from bovine feces and carcasses in Northeast Mexico. Front. Vet. Sci., 8: 643802.

41. Martínez-Vázquez, A.V., Rivera-Sánchez, G., Lira Méndez, K., Reyes-López, M.Á. and BocanegraGarcía, V. (2018) Prevalence, antimicrobial resistance and virulence genes of $E$. coli isolated from retail meat in Tamaulipas, Mexico. J. Glob. Antimicrob. Resist., 14: 266-272.

42. Naqid, I.A., Balatay, A.A., Hussein, N.R., Saeed, K.A., Ahmed, H.A. and Yousif, S.H. (2020) Antibiotic susceptibility pattern of $E$. coli isolated from various clinical samples in Duhok City, Kurdistan Region of Iraq. Int. J. Infect., 7(3): e103740.

43. Nguyen, V.T., Jamrozy, D., Matamoros, S., Carrique-Mas, J.J., Ho, H.M., Thai, Q.H., Nguyen, T.N.M., Wagenaar, J.A., Thwaites, G., Parkhill, J., Schultsz, C. and Ngo, T.H. (2019) Limited contribution of non-intensive chicken farming to ESBL-producing E. coli colonization in humans in Vietnam: An epidemiological and genomic analysis. J. Antimicrob. Chemother., 74(3): 561-570.

44. Bourély, C., Cazeau, G., Jarrige, N., Jouy, E., Haenni, M., Lupo, A., Madec, J.Y., Leblond, A. and Gay, E. (2019) Co-resistance to amoxicillin and tetracycline as an indicator of multidrug resistance in $E$. coli isolates from animals. Front. Microbiol., 10: 2288.

45. Laroche, E., Pawlak, B., Berthe, T., Skurnik, D. and Petit, F. (2009) Occurrence of antibiotic resistance and class 1, 2 and 3 integrons in $E$. coli isolated from a densely populated estuary (Seine, France). FEMS Microbiol. Ecol., 68(1): 118-130.

46. Cambrea, S.C. (2014) Antibiotic susceptibility of E. coli strains isolated in a pediatric population from South-Eastern Romania. J. Pediatr. Infect. Dis., 9(3): 157-162.

47. Kibret, M. and Abera, B. (2011) Antimicrobial susceptibility patterns of $E$. coli from clinical sources in Northeast Ethiopia. Afr. Health Sci., 11(1): S40-S45.

48. Ljubojević, D., Velhner, M., Todorović, D., Pajić, M. and Milanov, D. (2016) Tetracycline resistance in E. coli isolates from poultry. Vet. Arhiv, 9(1): 61-81.

49. Ljubojević, D., Pelić, M., Puzaca, N. and Milanov, D. (2017) Resistance to tetracycline in E. coli isolates from poultry meat: Epidemiology, policy and perspective. Worlds Poult. Sci. J., 73(2): 409-417. 